\title{
Evaluation of Distance Learning at Public Middle School Jakarta
}

\author{
Amirudin', Siti Rochana 2, Suryadi3
}

DOI: $10.35445 /$ alishlah.v13i2. 777

\begin{tabular}{l}
\hline Article Info \\
\hline Keywords: \\
Education; \\
Distance Learning; \\
Online
\end{tabular}

Kata kunci:

Pendidikan;

Pembelajaran Jarak

Jauh;

Daring

\begin{abstract}
Distance learning is a solution to the conditions during the Covid-19 pandemic so that the educational process remains organized and productive. The purpose of the study was to obtain the results of the evaluation of distance learning at SMP Negeri Jakarta. This study used the descriptive qualitative method. Data collection techniques consist of observation, documentation, and interviews. The data collection process includes data collection, data reduction, data presentation, and concluding. The results of the study show that the implementation of distance learning still faces technical and non-technical obstacles, such as the readiness of facilities and infrastructure, teaching materials, readiness of students and parents in providing internet networks, pedagogical and professional competencies of teachers that are relevant to knowledge and technological advances. However, overall, distance learning activities have had a significant impact on the achievement of educational goals.
\end{abstract}

\begin{abstract}
Abstrak
Pembelajaran jarak jauh menjadi solusi dari kondisi saat pandemic Covid-19 agar proses pendidikan tetap diselenggarakan dan produktif. Tujuan penelitian adalah untuk mendapatkan hasil evaluasi pembelajaran jarak jauh di SMP Negeri Jakarta. Penelitian ini menggunakan metode deskriptif kualitatif. Teknik pengumpulan data terdiri dari observasi, dokumentasi, dan wawancara. Proses pengumpulan data meliputi pengumpulan data, reduksi data, penyajian data dan penarikan kesimpulan. Hasil penelitian menunjukkan bahwa pelaksanaan pembelajaran jarak jauh masih menghadapi kendala baik secara teknis dan non-teknis, seperti kesiapan sarana dan prasarana, materi ajar, kesiapan siswa dan orang tua dalam menyediakan jaringan internet, kompetensi pedagogik dan profesional guru yang relevan dengan pengetahuan dan kemajuan teknologi saat ini. Namun, secara keseluruhan kegiatan pembelajaran jarak jauh telah memberikan dampak yang besar terhadap pencapaian tujuan pendidikan.
\end{abstract}

\footnotetext{
${ }^{1}$ Universitas Negeri Jakarta, Indonesia Email: amirudinibusidik30@gmail.com 2 Universitas Negeri Jakarta, Indonesia Email: sitirochanah@unj.ac.id

3 Universitas Negeri Jakarta, Indonesia Email: suryadi@unj.ac.id
} 


\section{INTRODUCTION}

The Covid-19 period demands teachers as educators, still required to carry out education in schools. Learning is required to continue so that education is guaranteed. The essential duties and functions of the inherent teacher must still be carried out because teachers are expected to carry out their education and learning, so teachers are required to be creative as facilitators in learning. With the independent learning program, teachers are expected to have more professional competencies and be able to realize the concept and carry out independent learning well. Distance learning is learning that prioritizes independence. Teachers can convey learning to students without having to meet face to face in the same room. This kind of learning can be done at the same time or at different times. Distance Learning is learning by using media that allows interaction between teachers and students. In implementing distance learning, what must be strived for are facilities and infrastructure that support online learning, such as infrastructure for strengthening the internet network, Learning Management System (LMS), and increasing the capacity of educators who support. Therefore, all parties involved in the implementation of education must provide full support (Al Siyabi et al., 2021)

There is some problem in the implementation of distance learning policies. Some students cannot understand the use of smartphones to carry out distance learning and have access to internet networks. Students in Jakarta also still have limitations in providing quotas. In addition, several difficulties are encountered when implementing a distance learning both offline and online, including a) Internet network, so that online and offline learning systems can run effectively if the internet network is good. On the other hand, the online teaching and learning process will automatically be hampered when the internet network is terrible. b) Limited internet quota. Parents affected by Covid-19 will find it challenging to buy an internet quota. This needs to be considered carefully by the school and the Ministry of Education and Culture, especially during the COVID-19 pandemic. c) Ineffective teaching and learning process. Online and offline learning systems are certainly not as effective as learning in schools. This is due to several factors, for example, the reduction in teaching hours. Teachers who usually teach for 4 hours at school are forced to only teach for one hour. It made it difficult to attract students to the learning process (Lapitan et al., 2021). It impacts students who have difficulty understanding much material in a relatively short time with different content of competency achievements. Thus, parents must also assist students in learning. However, parents face all kinds of obstacles in helping their children study at home (Abuhammad, 2020).

This research needs to be carried out from these problems because distance learning activities require periodic evaluations so that all obstacles or problems encountered can be resolved. Many studies have addressed the problems of distance learning. However, the concept of distance learning is considered feasible as an appropriate substitute during the COVID-19 pandemic (Sutiah et al., 2020; Mishra et al., 2020). It is implemented using learning platform online resources (Arulogun et al., 2020). It means that ICT improved the efficiency of the education system (Bidarian et al., 2011). Teachers can use various online learning modes (Mishra et al., 2020). Open and Distance Learning (ODL) students rely heavily on the use of Information, Communication, and Technology (ICT) tools for online facilitation and other activities that support learning (Arulogun et al., 2020; Holmgren, 2012; Shen et al., 2017). Thus, learning activities carried out online can provide the effectiveness and quality of education held in schools if carried out properly and all learning facilities are available (Yanuschik et al., 2015).

Thus, this study aims to determine the results of distance learning at Public Middle School Jakarta during the covid-19 pandemic. The research results are also expected to provide benefits for online teaching and learning activities by utilizing various digital platforms according to the needs of students, student backgrounds, and schools. Also, the research results can be used as a reference in conducting evaluation studies on the implementation of distance learning education programs to provide quality and better education services in the future. 


\section{METHODS}

The participant of the study was the school principal in Duren Sawit District. They are 78 people. This study explored the phenomenon of distance learning at Public Middle School Jakarta. It described the symptoms in the research problem, which are related to implementing actions for distance learning programs in the Covid-19 Period at State Junior High Schools in Duren Sawit District systematically and by the facts available in the area research (Creswell, 2012). It used the descriptive qualitative method. Data collection techniques consist of 1 . Observation is done to observe the process of distance learning. The researcher joined in the online learning. 2. Documentation is a document of learning evaluation from the teacher and school principal. 3 . Interviews addressed school principals. The data collection process includes data collection, data reduction, data display, and conclusion (Miles \& Huberma, 1992).

\section{FINDINGS AND DISCUSSION}

The result of data analysis showed in the below graph;

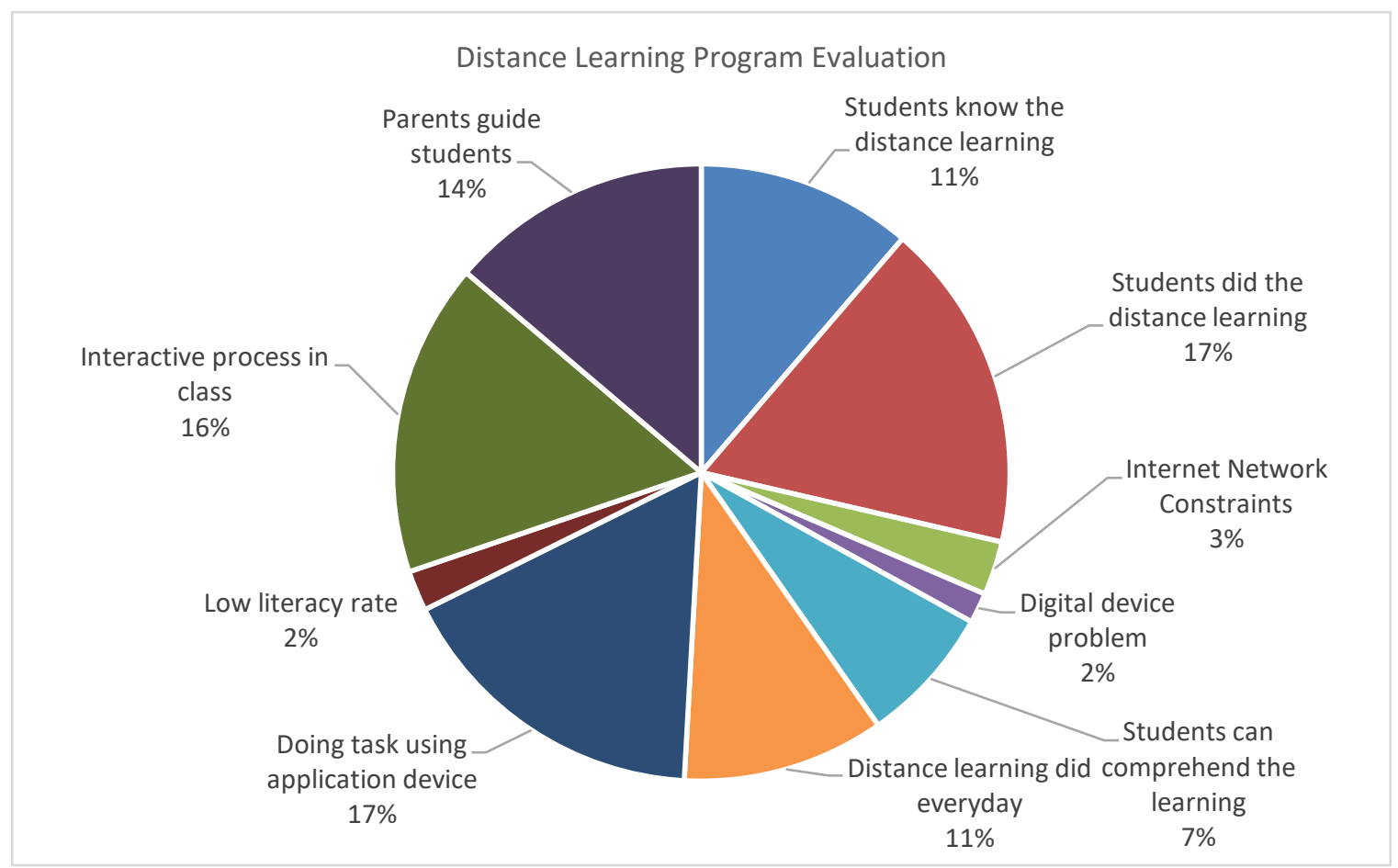

Graph 1. Percentage of Distance Learning Evaluation

Graph 1 shows that most students know about distance programs/study from home as much as $64.2 \%$ and some students do not know about it as much as $32.8 \%$, and the remaining $3 \%$ of students know through the internet by accessing themselves. It shows that students have started to adapt by studying distance learning programs from home by accessing educational platform services directed by teachers, and learning from online tutorials on the internet. It is around $98.5 \%$ which students carried out the distance learning program well during COVID-19 and did not implement it. It means that students try to follow distance learning carefully according to the direction of the teacher, even though there are also students who experience boredom in participating in online learning on the grounds of being tired and lazy to take online learning. In contrast, the teacher felt the exhaustion for classroom management (Sokal et al., 2020). During learning from home, 41.8\% of students felt that they could absorb learning quite well. One of the causes of students not being able to absorb knowledge well during online learning is the loss of focus and boredom, causing a sense of laziness, or the method used by the teacher is always the same every day.

The number of students who do online learning activities every day is $60 \%$. In carrying out learning from home, $95.5 \%$ of students are working on questions from the teacher given via WhatsApp, google form or google classroom. $65.7 \%$ of students learn from textbooks, $38.8 \%$ of 
students learn interactively with teachers, $38.8 \%$ of students learn from online learning applications, and $49.3 \%$ of students can do simple tasks, $82.1 \%$ of students can learn using various internet media sources and others. Student literacy activities during distance learning are $11.9 \%, 7.5 \%$ of students learn from TV. Interaction with teachers in distance learning during the covid-19 pandemic was 92.5\%, students interacted through online classes provided by teachers (google classrooms, virtual home learning classes, quiver school, and others). During the learning process, parents also help accompany students, which is $78 \%$.

Teachers find it difficult to motivate the learning process because students feel that they are not supervised, primarily since both parents work, so no one guides them to study. The teacher has repeatedly delivered learning through learning media such as google classroom or zoom meeting. Students sometimes do not even open Google Classroom, even though all the material and explanations have been delivered. This makes it difficult for the teacher to know whether the student has understood what is being conveyed to achieve the Minimum Completeness Criteria. In guiding students, teachers are ready to be contacted at any time in terms of helping students complete their assignments. Meanwhile, in responding to the student learning process, the problem is giving a warning to students who have never been active in Google Classroom, even though it is enough to fill in the attendance list provided or comment is already considered present

In terms of increasing distance learning, the government supports and facilitates the implementation of online learning more broadly, collaborating with the Ministry of Communication and Information and telecommunications service providers. Then, the public can access various distance learning content through various platforms such as Rumah Belajar, Kelas Pintar, Quipper School, Ruang Guru, and Zenius to support distance learning. As a form of support, the government encourages the priority of Learning Houses to work together with the Public Broadcasting Institute, TVRI, and RRI so that an IT-based learning system can be utilized when problems occur on the internet network. It means that IT is the significant framework for distance learning (Parra et al., 2021; Sailer et al., 2021).

Based on the research results, online tutorials using a learning management system helps teachers and students carry out distance learning activities. Online learning, it is today, tends to take advantage of applications or platforms (Adnan, 2020)such as Zoom, followed by WhatsApp and Google Meet with material explained in some online presence. Filling in attendance is also done online, either by using Google Documents or other platforms depending on the school's policies and the teachers who teach.

Generally, students who feel comfortable studying from home have economic capabilities that support the learning process because sophisticated devices support it and the needs met while studying home. The economic and educational background is also one of the important factors that cause growth in students' enthusiasm in participating in learning from home because they do not have obstacles about the quota. Some students think that they cannot absorb lessons because they feel inferior due to the family's economic situation and parents' limited level of understanding in guiding students from home to use gadgets or educational platforms (Adnan, 2020). So, to overcome this, the school provides free wifi services for students with poor family economic conditions to be able to do their online assignments at school by limiting the number of students and borrowing devices from schools in the form of cellphones or laptops owned by the school to support and provide access fair education for students, so that they can continue to learn. In this case, the principal's leadership role is not spared by making a breakthrough with the school community, especially the parent committee.

The interview results concluded that some of the obstacles faced during distance learning activities are constraints on access to network connections, device constraints, problems with applications, the boredom of students while teaching and learning activities. It is taken from some point in interview results with school principals.

"During the implementation of distance learning, there is quota assistance. Schools conduct mapping, so that distance learning goes well. The deputy head of the school 
for student affairs always asks the teachers for reports to find out the difficulty of the quota. Then it is coordinated with representatives of parents in each class under the school committee (Principal of State Junior High School 255 Jakarta)."

"Parents complained that they could not catch the signal well in the apartment area. Then the principal provided a solution to come to school and consult with the school. The solution to the problem of students is that the school provides a place in the school to do distance learning but is not accompanied by friends so as not to miss the lesson (Principal of State Junior High School 255 Jakarta)."

"Teachers have difficulty in distance learning which is a new way in the virtual learning process. This requires skills in using technology and the relationship between teachers and students internalization, teachers also during distance learning must be extra patient in dealing with student attitudes and behaviors that are difficult to control because in conditions of distance and from home, they must often prepare children mentally to be ready to learn online or offline. This is certainly not easy because children have a psychological learning burden when they do not complete learning to the fullest. Some students think that offline is an interest in learning. (Principal of State Junior High School 255 Jakarta)."

As another study concluded that many students think offline learning is more understandable (Patricia Aguilera-Hermida, 2020; Coyne et al., 2018) than online and others. Distance learning has advantages that cannot be obtained when learning online, such as learning which tends to be more relaxed. Students can rest their bodies easily if there is a time lag during learning because they are at home, so students tend to be more relaxed in following each lesson. In addition, another advantage of this distance learning system is that students do not need to be burdened with the cost of going to school because all learning is carried out at home. Students also only need an internet connection that supports their learning activities in every teaching and learning activity. Even so, distance learning is one of the steps taken by the government to reduce the spread of the COVID-19 virus during the COVID-19 pandemic (Yusof \& Ahmad, 2012; Karakoyun \& Kavak, 2009).

\section{CONCLUSION}

The findings concluded that the problems found during distance learning were students were less able to understand the content of the material which had been presented through online media by the teacher, the internet network was sometimes disrupted, the lack of use of online learning media so that some subject matter needed learning tools and/or media certain areas and teachers have used various digital platform applications for learning activities. The school has tried to overcome these problems, such as holding training for teachers regarding the use of online learning media as using google classroom, google forms, making learning videos and so on. In addition, supporting facilities and infrastructure used by teachers in the learning process as strengthening the internet network have been built so that the distance learning process (online) can be carried out optimally.

This research is expected to be an input for schools to map children who can do online learning and who can only go offline or who can go offline and online. Schools are asked to prepare learning schedules and create learning modules for children who cannot go online. Teachers are directed to be more creative, reduce the child's workload during distance learning, and provide more free time for students. This research is still limited to the evaluation of distance learning. It has not been developed on student learning outcomes during the online learning process or parents' difficulties in accompanying their children during distance learning. Therefore, this research can still be continued on other themes or aspects that affect the success of distance learning.

\section{REFERENCES}

Abuhammad, S. (2020). Barriers to distance learning during the COVID-19 outbreak: A qualitative review from parents' perspective. Heliyon, 6(11), e05482. 
https://doi.org/10.1016/j.heliyon.2020.e05482

Adnan, M. (2020). Online learning amid the COVID-19 pandemic: Students perspectives. Journal of Pedagogical Sociology and Psychology, 1(2), 45-51.

https://doi.org/10.33902/JPSP.2020261309

Al Siyabi, H., Al Mukhaini, S., Kanaan, M., Al Hatmi, S., Al Anqoudi, Z., Al Kalbani, A., Al Bahri, Z., Wannous, C., \& Al Awaidy, S. T. (2021). Community Participation Approaches for Effective National COVID-19 Pandemic Preparedness and Response: An Experience From Oman. Frontiers in Public Health, 8. https://doi.org/10.3389/fpubh.2020.616763

Arulogun, O. T., Akande, O. N., Akindele, A. T., \& Badmus, T. A. (2020). Survey dataset on open and distance learning students' intention to use social media and emerging technologies for online facilitation. Data in Brief, 31, 105929. https://doi.org/10.1016/j.dib.2020.105929

Bidarian, S., Bidarian, S., \& Davoudi, A. M. (2011). A model for application of ICT in the process of teaching and learning. Procedia - Social and Behavioral Sciences, 29, 1032-1041. https://doi.org/10.1016/j.sbspro.2011.11.336

Coyne, L., Takemoto, J. K., Parmentier, B. L., Merritt, T., \& Sharpton, R. A. (2018). Exploring virtual reality as a platform for distance team-based learning. Currents in Pharmacy Teaching and Learning, 10(10), 1384-1390. https://doi.org/10.1016/j.cptl.2018.07.005

Creswell, J. W. (2012). Educational Research: Planning, Conducting, and Evaluating Quantitative and Qualitative Research. Pearson Education.

Holmgren, R. (2012). Preparations for Practical Exercises in Vocational Education: Can ICT-based Distance Instruction be an Alternative to Face-to-face Instruction? An Empirical Contribution. Procedia - Social and Behavioral Sciences, 46, 1152-1161. https://doi.org/10.1016/j.sbspro.2012.05.266

Karakoyun, F., \& Kavak, M. T. (2009). The opinions of academicians regarding distance learning: a sample of Dicle University. Procedia - Social and Behavioral Sciences, 1(1), 1172-1176. https://doi.org/10.1016/j.sbspro.2009.01.211

Lapitan, L. D., Tiangco, C. E., Sumalinog, D. A. G., Sabarillo, N. S., \& Diaz, J. M. (2021). An effective blended online teaching and learning strategy during the COVID-19 pandemic. Education for Chemical Engineers, 35, 116-131. https://doi.org/10.1016/j.ece.2021.01.012

Miles, \& Huberma. (1992). Analisis Data Kualitatif. Universitas Indonesia Press.

Mishra, L., Gupta, T., \& Shree, A. (2020). Online teaching-learning in higher education during lockdown period of COVID-19 pandemic. International Journal of Educational Research Open, 1, 100012. https://doi.org/10.1016/j.ijedro.2020.100012

Parra, C. M., Gupta, M., \& Mikalef, P. (2021). Information and communication technologies (ICT)enabled severe moral communities and how the (Covid19) pandemic might bring new ones. International Journal of Information Management, 57, 102271. https://doi.org/10.1016/j.ijinfomgt.2020.102271

Patricia Aguilera-Hermida, A. (2020). College students' use and acceptance of emergency online learning due to COVID-19. International Journal of Educational Research Open, 1, 100011. https://doi.org/10.1016/j.ijedro.2020.100011

Sailer, M., Murböck, J., \& Fischer, F. (2021). Digital learning in schools: What does it take beyond digital technology? Teaching and Teacher Education, 103, 103346. https://doi.org/10.1016/j.tate.2021.103346

Shen, C. W., Kuo, C. J., \& Ly, P. T. M. (2017). Analysis of social media influencers and trends on online and mobile learning. International Review of Research in Open and Distance Learning, 18(1), 1-224. https://doi.org/10.19173/irrodl.v18i1.2640

Sokal, L., Trudel, L. E., \& Babb, J. (2020). Canadian teachers' attitudes toward change, efficacy, and burnout during the COVID-19 pandemic. International Journal of Educational Research Open, 1, 100016. https://doi.org/10.1016/j.ijedro.2020.100016 
Sutiah, S., Slamet, S., Shafqat, A., \& Supriyono, S. (2020). Implementation of distance learning during the covid-19 pandemic in faculty of education and teacher training. Cypriot Journal of Educational Sciences, 15(5), 1204-1214. https://doi.org/10.18844/cjes.v15i5.5151

Yanuschik, O. V., Pakhomova, E. G., \& Batbold, K. (2015). E-learning as a Way to Improve the Quality of Educational for International Students. Procedia - Social and Behavioral Sciences, 215, 147-155. https://doi.org/10.1016/j.sbspro.2015.11.607

Yusof, A. N. M., \& Ahmad, N. L. (2012). An Investigation on the Relationship between Online Distance Learning with Learning Usability. Procedia - Social and Behavioral Sciences, 65, 1066-1070. https://doi.org/10.1016/j.sbspro.2012.11.372 